\title{
Die evaluering van 'n visgesondheidsindeks in die Olifantsrivieropvanggebied
}

\author{
R.M. Watson en A. Avenant-Oldewage \\ Departement Dierkunde, Randse Afrikaanse Universiteit, Posbus 524, Aucklandpark, 2006
}

In die verlede is beperkte welslae met gelokaliseerde watermonsters verkry, gevolglik word biologiese moniteringsisteme in "Il toenemende mate internasionaal gebruik. Hierdie sisteme gee vinnig ' $n$ indikasie van die gesondheid van ' $n$ bepaalde ongewing.

Gedurende die huidige studie is 'n visgesondheidsindeks as biologiese moniteringsisteem in vier lokaliteite geëvalueer. Twee van hierdie lokaliteite was damme, Loskopdam (besoedeld) en Bronkhorstspruitdam (kontrole), geleë in die bolope van die rivier. Die oorblywende twee lokaliteite was stroomaf en geleë in die rivier, by Mamba (besoedeld) en Balule (kontrole) in die Nasionale Kruger-wildtuin. Die damme is in al vier seisoene geevalueer en die riviere slegs in die somer en winter.

Interne organe, vetinhoud, bloedwaardes, die aanwesigheid van parasiete en die toestand van buite oppervlaktes van die vis word gebruik om 'n aanduiding te gee van die gesondheid van die vis. 'n Numeriese waarde word verkry wat die gesondheid van elke vis voorstel. "n Minimum steekproef van twintig visse word gebruik, en 'n gemiddelde waarde bepaal die visgesondheid van 'n spesifieke lokaliteit. Alhoewel die oorsprong van besoedeling nie met gebruik van hierdie indeks bepaal kan word nie, bied die indeks 'n nuttige manier om die vis se gesondheidsprofiel te gebruik om besoedelingsvlakke in ' $n$ akwatiese ekosisteem te evalueer. Swaarmetaalanalise, deur gebruik van Atoomabsorpsiespektrofotometrie is as deel van die studie gebruik ten einde die resultate van die visgesondheidsindeks te ondersteun. Die Akwatiesetoksisiteitsindeks ('n rekenaarprogram) is ook gebruik om swaar metale in die sediment en water as 'n enkelsyfer uit te druk, wat ook gebruik word om die visgesondheidsindeks te staaf. Parasiete (een van die aanwysers van die visgesondheidsindeks) is voorts ook as ' $n$ onafhanklike indeks gebruik ten einde te bepaal of dit as aanwyser van besoedeling kan dien, ektoparasiete en endoparasiete is apart geèvalueer.

Die visgesondheidsindeks het verskille tussen die vier lokaliteite uitgewys. Loskopdam was meer besoedel as Bronkhorstspruitdam, terwyl die lokaliteit by Mamba meer besoedel voorgekom het as die by Balule. Die waardes verkry vir lewer en bloed, sowel as die aantal parasiete teenwoordig, het as die duidelikste veranderlikes uitgestaan. Swaarmetaalanalise dui daarop dat die meeste bioakkumulering in die kieu- en lewerweefsel plaasvind en dat 'n korrelasie tussen die gesondheidsindekswaardes en metaalwaardes bestaan. Die Akwatiesetoksisiteitsindeks staaf ook die bevindinge van die visgesondheidsindeks en metaalwaardes. Die parasietindeks het wel as goeie aanwyser van besoedeling gedien. Daar is bevind dat daar by meer besoedelde lokaliteit laer getalle ektoparasiete is, terwyl endoparasietgetalle hoër is. Hierdie verhoudingsgetal dien dus as aanduiding van waterbesoedelingsvlakke.

Statistiese vergelykings kan dus getref word tussen twee of meer lokaliteite as die visgesondheidsindeks gebruik word. Deur net gebruik te maak van die lewer, bloed en visparasiete, kan die indeks vereenvoudig word, maar dit is net tydens gebruik in die Olifantsriviersisteem. Die visgesondheidsindeks moet nog in 'n ander riviersisteem getoets word voordat enige aannames gemaak kan word oor die finale aanpassing van die indeks onder SuidAfrikaanse toestande. Met die gebruik van parasiete as ' $n$ afsonderlike indeks, word die evaluering van die akwatiese omgewing nog verder vereenvoudig. Hierdie nuwe biologiese moniteringsisteem kan ook gesien word as 'n manier om die visgesondheidsindeks te ondersteun aangesien hierdie indeks naastenby dieselfde resultate aangetoon het.

Die visgesondheidsindeks en parasietindeks kan dus wel gebruik word om die waterkwaliteit tussen twee of meer lokaliteite te vergelyk.

\section{Genetiese tipering van inheemse ras-egte en basterhonde afkomstig van agtergeblewe bevolkingsgemeenskappe}

\author{
L. Greyling en F.H. van der Bank \\ Departement Dierkunde, Randse Afrikaanse Universiteit, Posbus 524, Aucklandpark, 2006
}

J.P. Grobler

Departement Dierkunde en Biologie, Universiteit van die Noorde, Privaat sak X1106, Sovenga, 0727

\author{
A. Kotze \\ Diereverbeteringsinstituut, Privaat sak X2, Irene, 1675
}

Argeoloë het wetenskaplike bewyse gevind dat Afrikagemeenskappe in die Ystertydperk hul lewens met gedomestikeerde honde
(Canis familiaris) gedeel het, lank voor die aankoms van enige Westerse invloede. 'n Oeroue, inheemse ras van Afrika-honde, 
moontlik van die oudste ter wêreld, mag uitsterf as gevolg van verbastering met Europese rasse. Binne Afrika-gemeenskappe word die teling van honde hoofsaaklik gebaseer op seleksie deur die natuur. eerder as deur die mens. Dié honde het hulle eie, ingebore gedragspatrone waar dominansie tussen rasse 'n moontlike rol speel, wat hulle natuurlike voortplantingspatrone help verseker. Deur honde vanaf hierdie meer informele gebiede te bestudeer, kan vasgestel word watter genetiese variasie daar binne dié rasse bestaan (d.w.s. die inheemse spesies geneties tipeer), en sodoende help om hulle te bewaar.

In hierdie studie is bloedmonsters geneem van die inheemse (Sica) ras, gevestig in KwaZulu-Natal, asook kontrolerasse, naamlik basterhonde vanaf verskeie informele nedersettings en Dierebeskermingsverenigings. As ' $n$ verdere kontrole is bloed van 'n Israeli-honderas (die Saluki's) ook geanaliseer. Meer as $200 \mathrm{~b}$ loedmonsters is geanaliseer om genetiese inligting te bekom.
In samewerking met die Diereverbeteringsinstituut (Landbounavorsingsraad) is standaard elektroforetiese en proteïenpolimorfisme-studies gebruik om die genetiese variasie binne rasse, tipering en genetiese afstande tussen rasse te bepaal. Verskeie ensieme is geanaliseer m.b.v. poliakrielamiedjelelektroforese (PAGE) en styseljelelektroforese (23 proteïenkoderende lokusse).

Nege polimorfiese lokusse is geïdentifiseer: AK-1, -2, CK, PER, Hb, PA-1, -2, -3 en P-Tf. Die gemiddelde heterosigositeitwaardes was van 0,106 tot 0,182 , terwyl die genetiese afstande tussen 0,001 en 0,035 was, met die kleinste afstand tussen die Sicaen Israeli-groepe. Statistiesbeduidende verskille $(\mathrm{P}<0,05)$ is gevind tussen die rasse by veral post-transferien. Hierdie resultate dui daarop dat die Sica-ras geneties afgesonderd is van die ander rasse wat bestudeer is.

\section{Teenstrydighede in die morfologie van Mugilicola-spesies}

\section{Annemarié Avenant-Oldewage}

Departement Dierkunde, Randse Afrikaanse Universiteit, Posbus 524, Aucklandpark, 2006

Vier spesies van die genus Mugilicola is tot op hede beskryf. Hierdie organismes is in onderskeidelik Indië, Irak, Australië en Suid-Afrika versamel. Die Suid-Afrikaanse verteenwoordiger, Mhrgilicola smithae, is vanaf palings in 'n rivier in die Oos-Kaap versamel. Hierdie spesie word uitgeken aan die trilobiese uitsteeksels aan die kop van volwasse parasitiese wyfies. Die parasiete vestig hulle op die kieue van hul gashere en twee derdes van die parasietliggaam word deur die gasheerweefsel verberg. Hulle groei tot binne-in die kraakbeenweefsel van die kieueboog en word voorts bedek deur' $n$ bindweefselkapsel wat deur die gasheer gesekreteer word.

Tydens in onlangse studie is verteenwoordigers van hierdie parasietgroep vanaf die kieue van harders in die Nhlabaneestuarium versamel. Aangesien die studie oor 'n aantal seisoene verloop het, is heelwat parasiete, verteenwoordigend van alle parasitiese ontwikkelingsfases, versamel. Waterkwaliteit is bepaal.

Hierdie organismes is geidentifiseer as $M$. smithae, die spesie wat reeds vantevore in Suid-A frika gevind is. Daar is egter bevind dat die trilobiese uitsteeksels se vorm hoegenaamd nie konstant is nie, maar wissel vanaf baie prominente strukture tot en met byna afwesig. Daar was voorts ook geen verband tussen die grootte van die uitsteeksel en die ontwikkelingstadium van die parasiet nie. Geen korrelasie is gevind tussen die prominensie of grootte van die uitsteeksel met die tyd van die jaar, of die waterkwaliteit nie. Die parasiet se ontwikkelingsfase het ook nie 'n ooreenkoms met die grootte van die uitsteeksels getoon nie.

Daar word voorgestel dat die vorm van die uitsteeksels bepaal word deur die posisie op die gasheer eerder as deur die parasiet. 'n Organisme wat in sagte weefsel ingroei, sal meer prominente trilobiese uitsteeksels besit, terwyl een wat in kraakbeen ingroei oor minder prominente uitsteeksels sal beskik.

Aangesien hierdie strukture nie konstant voorkom nie, word aanbeveel dat die gebruik van die morfologie daarvan nie voortaan as taksonomiese kenmerk in ag geneem behoort te word nie. Die implikasie van hierdie aanbeveling is dat alle spesies in die genus hersiening sal moet ondergaan.

\section{'n Ligmikroskoopstudie van 'n verteenwoordiger van die Diplozoidae versamel in die Vaaldam vanaf Barbus aeneus}

\section{Hempel en A. Avenant-Oldewage}

Departement Dierkunde, Randse Afrikaanse Universiteit, Posbus 524, Aucklandpark, 2006

Die familic Diplozoidae is ' $n$ baie unieke takson van die groep Monogenea. Die organismes word daardeur gekenmerk dat twee volwasse wurms permanent versmelt in die vorm van die letter $\mathrm{x}$, en dat die wurmpaar op visse se kieue parasiteer.

In Afrika is slegs 'n paar spesies gedokumenteer, naamlik Diplozoon cregyptensis uit Egipte, Kenia en Uganda vanaf $l$ abeo spp. en Barbus spp versamel; D. ghanense op Alestes macrolepiclortus in Ghana en Neodiplozoon polycotyleus vanaf Labeo spp. en Barbus spp. in Kenia en Tanzanië.

Barbus aeneus (die kleinbek-geelvis), 'n moontlike gasheervisspesie, is met behulp van kieunette in die Vaaldam versamel. Die visse is gedood en die kieue is verwyder. Daarna is die parasiete met behulp van ' $n$ disseksiemikroskoop bestudeer en van die kieue af verwyder. Parasiete is lewendig afgeplat en gefikseer in warm asetoformaldehied-alkohol. Vir die ligmikroskoopstudie is totaalpreparate voorberei en onderskeidelik gekleur met behulp van borakskarmyn-jodium en hematoksilien.

Die parasiet is relatief groot in vergelyking met die gasheer se kieufilamente, naamlik ongeveer $3,3 \mathrm{~mm}$. Anterior besit die wurm twee bukale suiers en 'n gespierde farinks wat oorgaan na 'n hoogs vertakte intestinum. Die posteriorgedeelte bevat die geslagstelsel van hierdie hermafroditiese wurm en 'n opisthaptor met vier pare klampe asook 'n eier sonder 'n filament. Op grond van bogenoemde eienskappe word die gevolgtrekking gemaak dat hierdie organisme 'n verteenwoordiger is van die Paradiplozoongenus. Die groep is nog nie vantevore in Afrika gevind nie 


\title{
Die effek van omgewingstoestande op swaarmetaalkonsentrasies in die Olifantsrivier-sisteem
}

\author{
R.M. Watson en A. Avenant-Oldewage \\ Departement Dierkunde, Randse Afrikaanse Universiteit, Posbus 524, Aucklandpark, 2006
}

'n Vergelykende studie (droogte vs. vloede) om verskille in waterkwaliteit tussen twee damme en twee rivierpunte te bepaal, is in die Olifantsrivier-opvanggebied onderneem. Die twee damme, Loskopdam (besoedeld) en Bronkhorstspruitdam (kontrole) is in die bolope van die Olifantsriviersisteem geleë, en die rivierpunte, Mamba (besoedeld) en Balule (kontrole) verder stroomaf.

Fisiese en chemiese analises van water-en sedimentmonsters is gedoen, en bioakkumuleringstoetse vir die aanwesigheid van nege metale in die lewer-, vel-, spier-en kieuweefsel van Clarias gariepinus.

Die waterkwaliteit by die twee kontrolepunte het direk na die vloede verswak. Die waardes by hierdie twee lokaliteite was gelyk aan, of selfs hoër as die wat gemeet is vir metale by die twee besoedelde lokaliteite. Gedurende die daaropvolgende opnames het die waterkwaliteit by al vier lokaliteite verbeter, en tydens die someropname, 'n jaar na die vloede, het besoedelingsvlakke teruggekeer na dit wat voor die vloede gemeet is.

Die bioakkumuleringstudie het gewys dat metaalkonsentrasies die hoogste was in die kieuweefsel, en hoè konsentrasies is ook in die lewer- en velweefsel gemeet.

Verhoogde watervlakke as gevolg van die vloede het 'n verdunningseffek gehad, maar gifstowwe het vanaf gebiede in die bolope ingespoel, en oppervlakdreinering het voorgekom. Die verwydering van rietbeddings stroomop van Balule en by die inloop tot Bronkhorstspruitdam, het veroorsaak dat latente slik wat metale en organiese besoedelingstowwe bevat het, vrygelaat is. Hierdie gebeure het die verslegting in waterkwaliteit tot gevolg gehad.

Die kieue is die vernaamste weefsel vir metaalabsorpsie en ekskresie. Hoë konsentrasies in die lewerweefsel bewys dat detoksifisering plaasgevind het. Lae konsentrasies in die spierweefsel dui daarop dat die lewer effektief was ten opsigte van detoksifisering van die organisme. Konsentrasies in die vel is "n aanduiding van die aanwesigheid van produkte van ekskresieprosesse in die organisme. Die voorkeurvolgorde van konsentrasies in die onderskeie weefseltipes, naamlik kieue $>$ lewer $>$ sel $>$ spier, was naastenby dieselfde as die verkry deur ander navorsers voor die vloed, maar die orde van die konsentrasies in vel en spier was dikwels omgeruil. Dit kan toegeskryf word aan die toename in ekskresie van metale via die vel, na verhoogde blootstelling aan die metale tydens die vloede.

Die gevolgtrekking uit bogenoemde is dus dat ' $n$ toename in die blootstelling aan metale en organiese besoedelingstowwe, beskermende meganismes in die organisme geaktiveer het, wat eliminering van metale veroorsaak het voordat hulle in die spierweefsel gestoor kon word. Die algemene gesondheidstoestand van die vis by al vier lokaliteite in die Olifantsriviersisteem het dus nie verswak nie alhoewel die waterkwaliteit verswak het.

\section{'n Skandeerelektronmikroskoop-studie van 'n Paradiplozoon-spesie}

\author{
Annelize Cilliers en A. Avenant-Oldewage \\ Departement Dierkunde, Randse Afrikaanse Universiteit, Posbus 524, Aucklandpark, 2006
}

Verteenwoordigers van die Diplozoidae is buitengewoon in die sin dat die parasietliggaam uit twee volwasse individue in permanente kopulasie bestaan, met die geslagsorgane van beide individue in verbinding met mekaar. 'n Paradiplozoon-spesie, versamel vanaf die kieue van Barbus aeneus (kleinbek-geelvis) wat in die Vaaldam voorkom, is vir makromorfologiese kenmerke met behulp van die skandeerelektronmikroskoop (SEM) bestudeer, nadat die parasiet in asetoformaldehied-alkohol (AFA) gefikseer is en daarna gevriesdroog, opgedamp en met goud bedek is.

Uitwendig is die parasietliggaam met ' $n$ dik ongesilieerde kutikula, met transversale uitstulpings bedek. Dit het tot gevolg dat die liggaam oppervlakkig gesegmenteerd voorkom. Die prohaptorale streek van die parasietliggaam word gekenmerk deur die aanwesigheid van twee oraalsuiers en 'n mondopening, wat onderskeidelik as vassuig- en voedingsmeganismes dien. Die versmeltingswyk verteenwoordig die area waar versmelting tussen die twee individue in die larwale stadium plaasgevind het. Die enigste skeidslyn tussen die twee individue in kopulasie is deur die frontaalspierlaag. Die opisthaptorale streek bevat die vashegtingsorgane wat uit vier paar vashegtingskloue en een paar mediane hake bestaan

In die huidige studie is bevind dat alhoewel Labeo capensis (Oranjerivier-moddervis) en Barbus aeneus in die opname versamel is, die parasiet slegs op B. aeneus voorkom, met in relatiewe digtheid van 0,78 en persentasie besmetting van $50 \%$. Hieruit is afgelei dat die parasiet oor ' $n$ voorkeurgasheer asook voorkeurposisie op die gasheer beskik, en 'n maksimum infestasie van drie parasiete per vis is aangeteken. Hierdie lae gemiddelde besmettingsintensiteit dui waarskynlik daarop dat die parasiete nie onder normale veldtoestande tot die dood van hul gashere sal lei nie 


\title{
Die effek van koper op die histologie van die testis van Oreochromis mossambicus
}

\author{
G.M. Pieterse en J.H.J. van Vuren \\ Departement Dierkunde, Randse Afrikaanse Universiteit, Posbus 524, Aucklandpark, 2006
}

Chemiese stowwe in mynbou-, landbou-, industriële en stedelike uitvloeisels is potensiële besoedelstowwe van akwatiese ekosisteme wat 'n nadelige invloed op akwatiese lewe kan hê. Koper is een van die noodsaaklike spoorelemente in natuurlike water, maar menslike aktiwiteit veroorsaak konsentrasies wat akwatiese lewe nadelig beînvloed. Verskeie studies is reeds uitgevoer waar subletale koperkonsentrasies nadelige gevolge op vis gehad het. Min inligting met betrekking tot die effek van koper op die voortplantingspotensiaal van varswatervisse is bekend.

In hierdie studie is die histologie van die testis van Oreochromis mossambicus bestudeer nadat die visse an subletale koperkonsentrasies (koperchloried) blootgestel is. Blootstellings is in deurvloeisisteme in die laboratorium, vir 'n kort termyn ( 96 uur) by $23{ }^{\circ} \mathrm{C}$ uitgevoer. Voorbereiding, inbedding en kleuring van die testisweefsel vir ligmikroskopie is volgens standaardtegnieke uitgevoer. Om die patologiese veranderinge in die testis waar te neem, is die weefsel vergelyk met kontrolevis wat nie aan koper blootgestel is nie. Vir ligmikroskopie is die testisweefsel in Bouins-fikseermiddel en $10 \%$ gebufferde neutrale formalien (GNF) gefikseer.

Die bloukurper het een paar testis wat bilateraal in die dorsale gedeelte van die abdomen geleë is. Die testis is ' $n$ verlengde struktuur, omring deur 'n tunica albuginea en bestaan uit 'n aantal lobules. Tussen die lobules is interstisiële weefsel waarin bloedvate, kollageenweefsel en Leydigselle voorkom. In die kontrolevis was die lobules uitgewel. In die lobules is daar siste met ontwikkelende spermselle. Die ontwikkelende testis se lobules het nie 'n lumen nie en die lobule is gepak met siste. Die spermselle ontwikkel deur verdeling van die spermatogonia op die basaalmembraan. Die siste binne die lobules is in verskillende stadiums van ontwikkeling.

$\mathrm{Na}$ blootstelling aan koper was die lobules baie kleiner as die lobules van die kontrolevis waar die lobules uitgewel en vol spermatozoa was. Die siste binne die lobules was in verskillende stadiums van ontwikkeling, maar baie min spermatozoa en laatstadium spermatiede het voorgekom. Die spermatogene weefsel het weggetrek van die basaalmembraan. Meer bloedvate het in die interstisiële weefsel voorgekom.

Die wegtrek van weefsel vanaf die basaalmembraan by die kieue na blootstelling aan metaalbesoedelstowwe is al beskryf. Die rede hiervoor kan moontlik wees om die afstand tussen die besoedelstof en die selle te vergroot. Die basaalmembraan wat wegtrek van die interstisiële weefsel in die testis, veroorsaak dat die ontwikkelende spermselle in die middel van lobule konsentreer. Gevolglik vergroot die afstand tussen die ontwikkelende spermselle en die koper in die interstisiële weefsel. Uit die bostaande resultate blyk dit asof die blootstelling van vis aan subletale konsentrasie koper vir die kort termyn 'n negatiewe invloed op die voortplantingspotensiaal van vis kan hê.

\section{Genetiese variasie in twee bevolkings van Hoplosteth us atlanticus (orange roughy) van Namibië}

\author{
P.J. Theron, N.S. Flint en F.H. van der Bank \\ Departement Dierkunde, Randse Afrikaanse Universiteit, Posbus 524, Aucklandpark, 2006
}

Iloplostethus atlanticus (die orange roughy) is 'n relatief nuwe kommersieel ontginde visspesie en word tans as een van die wêreld se gunsteling seekosprodukte beskou. Die visse is op dieptes van $650-1500 \mathrm{~m}$ versamel. Monsters is versamel van twee bevolkings langs die kus van Namibië, naamlik NS $\left(22^{\circ} 07^{\prime}\right.$ tot $22^{\circ} 57^{\prime} \mathrm{S}$; $12^{\circ} 22^{\prime} 06^{\prime \prime}$ tot $\left.13^{\circ} 08^{\prime} 08^{\prime \prime O}\right)$ en S $\left(25^{\circ} 56^{\prime} 01^{\prime \prime} 27^{\circ} 01^{\prime} \mathrm{S}\right.$; $13^{\circ} 07^{\prime} 06^{\prime \prime}$ tot $\left.13^{\circ} 57^{\prime} \mathrm{O}\right)$. Geenprodukte van 22 proteïenkoderende lokusse is bestudeer deur middel van horisontale styseljelelektroforese. Waardes van $31,8 \%$ en $40,9 \%$ ( 0,95 betroubaarheidsinterval) is bereken vir die persentasie polimorfiese lokusse, en $0,137( \pm 0,047)$ en $0,143( \pm 0,042)$ vir die gemiddelde heterosigositeit van die NS- en S-bevolkings. Die onbevoordeelde genetiese afstand was 0,004 tussen die twee bevolkings en die gemiddelde fiksasie-indeks ( $\left.\mathbf{F}_{\mathrm{ST}}\right)$-waarde was 0,019 . Hierdie waardes is vergelykbaar met die resultate van 'n soortgelyke studie op hierdie visspesie in Nieu-Seeland, waar die persentasie van polimorfiese lokusse van $22,7 \%$ tot $38,1 \%(0,95)$ betroubaarheidsinterval) en heterosigositeitwaardes van $0,04( \pm 0,037)$ tot $0,125( \pm 0,044)$ gewissel het. Daar was statistiesbeduidende $(P<0,05)$ verskille tussen die twee bevolkings. Die genetiese differensiasie tussen die twee bevolkings sluit die moontlikheid van 'n globale totale toelaatbare vangskwota vir die visspesie uit en daar word voorgestel dat elke bevolking individueel bestuur word deur die gebruik van aanpasbare bestuurstrategieë soos geïmplementeer deur visserye in Nieu-Seeland. 


\title{
'n Loodsopname van plantparasitiese aalwurms op gholfbane in Suid- Afrika
}

\author{
A. Swart \\ Nasionale Versameling van Nematode, Afdeling Biosistematiek, LNR-Navorsingsinstituut vir Plantbeskerming, Privaat sak \\ X134, Pretoria, 0001
}

A.S. Schoeman

Departement Dierkunde en Entomologie, Universiteit van Pretoria, 0002

Op gholfbane in Suid-Afrika is daar reeds vir 'n geruime tyd opgemerk dat gras kol-kol vergeel, stadig groei en verwelk tydens droogte of hoë temperature en soms afsterf. Die simptome vertoon tipies soos 'n voedingsgebrek en mag met verloop van tyd na groot dele van die grasbedekkings van setperke en omliggende areas versprei. Die simptome stem baie ooreen met dit wat deur plantparasitiese aalwurms in ander wêrelddele veroorsaak word en daar is besluit om 'n loodsopname van aalwurms op geselekteerde gholfbane in Gauteng, Oos-Kaap, Wes-Kaap en Noordwes Provinsies uit te voer. Die volgende grassoorte is op setperke en skoonveld wat skadesimptome toon, gemonster: Pennisetum clandestinum (kikoejoe), Cynodon sp. (kweek), Agrostis palustris (bentgras), Poa anmua (wintergras) en Festuca pratensis (swenkgras). Sewe-en-veertig monsters is oor 'n tydperk van agtien maande geneem (1997/1998). Monsters is met behulp van 'n grondpons geneem. Die bogrondse dele en wortels is mikroskopies vir galvorming ondersoek voordat dit opgekap is. Die aalwurms is uit die opgekapte plantdele onttrek met behulp van die gewysigde Baermann-filtertegniek. Aalwurms is uit die grond geëkstraheer met die suikerflottasietegniek vir leem- en kleigronde en die gewysigde Baermann-filtertegniek vir sandgronde.
Die genera Criconemella, Ilelicotylenchus, Ileterodera. Meloidogyne, Mesocriconema, Paratrichodorus, Tylenchorhynchus en Xiphinema is tydens die huidige opname gevind en is ook erkende patogene van die gras van gholfbane in die buiteland. Die genera Paratrichodoris (stompwortelaalwurms), Ilemicycliophora (skede-aalwurms), Ilelicotylenchus (spiraalaalwurms), Scutellonema (spiraalaalwurms) en Xiphinema (dolkaalwurms) het in die hoogste getalle op die Suid-A frikaanse gholfbane voorgekom. Die genus Paratrichodorus het die algemeenste rondom die wortels van bentgras voorgekom, terwyl Sculellonema en Helicotylenchus die algemeenste aalwurm rondom die wortels van kikoejoe-gras was.

'n Aalwurmpopulasie kan as plantplaag beskou word as die aalwurm aktief reproduseer op die betrokke gewas; wanneer die aalwurm in die buiteland, op dieselfde plant, as plaag beskou word; en die eksemplare in opeenvolgende monsters in betekenisvolle getalle voorkom (meer as $50 / 100 \mathrm{~g}$ grond). As die bogenoemde kriteria in ag geneem word, is plantparasitiese aalwurms, alleen of in komplekse met ander grondpatogene, verantwoordelik vir die skade wat in grasbedekkings van gholfbane in Suid-A frika voorkom.

\section{Rotylench us capensis Van den Berg \& Heyns, 'n plantparasitiese aalwurm vanaf die Antarktiese vasteland}

\section{E. van den Berg}

Nasionale Versameling van Nematodes, LNR-Navorsingsinstituut vir Plantbeskerming, Privaat sak X134, Pretoria, 0001

Twee eksemplare van die plantparasitiese spiraalaalwurm Rotylenchus capensis Van den Berg is vir die eerste maal in die gruisgrond op twee binnelandse nunatakke in die Ahlınanryggengebied, westelike Dronning Maud-land, Antarktika, gevind. Een wyfie is op die Marsteinen nunatak versamel waar relatiewe groot mosplate teenwoordig is. 'n Mannetjie is gevind in gruisgrond vanaf Lorentzenpiggen, 'n nunatak, waarop mos nog nooit gevind is nie, maar wel korsmosse. Die enigste verskil tussen die twee eksemplare en die wat oorspronklik uit Suid-A frika beskryf is, is effense posterieure verlengings van die stekelknoppe. Die teenwoordigheid van $R$. capensis op die Antarktiese vasteland laat vrae ontstaan oor die herkoms en voortbestaan van hierdie spesies onder sulke koue en droë klimaatstoestande en die afwesigheid van vaskulêre plante waarop plantparasitiese aalwurms tradisioneel voed.

Alhoewel temperature in die somer tot benede vriespunt daal en dikwels tot $-40^{\circ} \mathrm{C}$ kan daal gedurende die winter word sommige gronde se temperatuur in die somer vir 'n paar uur gedurende die dag so hoog as $34^{\circ} \mathrm{C}$. Vir kort periodes is die temperatuur dus geskik vir voortlewing.

Droê toestande word periodiek verlig deur water van gesmelte ys en sneeu wat deur die wind rondgewaai word. Vogtoestande kan dus gedurende die somer vir kort periodes ook heel aanvaarbaar vir die aalwurms wees.

Werklike voeding van spiraalaalwurms op mosse en korsmosse is nog nie fisies waargeneem nie, maar assosiasies is al aangeteken te Spitzbergen en die Kanadese Arktiese gebiede.

Oënskynlik het $R$. capensis geleer om by dié ekstreme toestande aan te pas. Die feit dat die mannetjie met 'n larwale kutikula omhul was, wys dat die populasies lewensvatbaar is. Volgens die literatuur het ander nie-parasiete die tye en duur van hulle lewensiklus verleng of verkort om by sulke ekstreme toestande in die Antarktiese gebied aan te pas.

Die moontlikheid dat die twee aalwurms op ander maniere, soos bv. windverspreiding en verspreiding deur seestrome en voëls na die twee lokaliteite gedra is, is ondersoek, maar uitgeskakel. Kontaminasie van die grondmonsters op pad en in die laboratorium is ook uitgeskakel.

Daar word gespekuleer dat hierdie twee nematodes lede is van 'n groter populasie wat op Gondwanaland bestaan het en na afskeiding van die kontinente aangepas het. Dit is interessant dat die mosspesies Ceratodon purpureus wat op dieselfde nunatakke voorkom ook op Tafelberg voorkom. 


\title{
Die ultrastruktuur van die blougroenalg Oscillatoria simplicissima
}

\author{
A. Venter \\ Departement Plant- en Bodemwetenskappe, Potchefstroomse Universiteit vir Christelike Hoër Onderwys, Potchefstroom, \\ 2520
}

Oscillatoria simplicissima Gomont is 'n filamentagtige blougroenalg wat in 1984 in die Vaalrivier geïdentifiseer is. Opbloeie van die blougroenalg verstop watersuiweringsfilters, veroorsaak dat drinkwater sleg smaak, maak swem in riviere en damme onaangenaam of onmoontlik, en veroorsaak onwelriekende reuke as dit ontbind. Daarby kan ontbinding van die blougroenalge suurstof uit die water onttrek wat visvrektes kan veroorsaak. Sommige blougroenalge produseer toksiene wat 'n gesondheidsgevaar vir mens en dier inhou.

Die doel van die studie was om die ultrastruktuur van Oscillatoria simplicissima te bestudeer, as deel van 'n projek om die groei en fisiologie van die blougroenalg te ondersoek, in 'n poging om 'n manier te vind om opbloeie te beheer of te elimineer.

Oscillatoria simplicissima-monsters is gedehidreer in etanol en met koolstof en palladium bedek vir bestudering met die skandeerelektronmikroskoop. Vir die transmissie-elektronmikroskoop is die monsters in kakodilaatbuffer en osmiumtertoksied gefikseer, in etanol gedehidreer en gekleur met uranielasetaat en loodsitraat.

Soos die naam Oscillaloria simplicissima suggereer, bestaan die blougroenalg uit ' $n$ eenvoudige, onvertakte blougroen trigoom wat bedek is met 'n dun, deurskynende skede. Die punt van die trigoom is hemisferies met 'n effens verdikte membraan.

Die selwand bestaan uit 4 korrelrige lae (L1-L4) tussen die plasmamembraan en die skede. Lae $I$ en 3 is elektrondeurlaatbaar en lae 2 en 4 is elektrondig. Gedurende mitose ontwikkel dwarswande sentripetaal van die buitenste longitudinale wand van die trigoom. Tussen die selle word 'n laag aangetref wat herinner aan die middellamella van hoër plante. Die plasmamembraan verskyn as 'n tipiese differensieel deurlaatbare eenheidsmembraan wat ook betrokke is in die vorming van selwande en tilakö̈edes.

Oscillatoria simplicissima is 'n prokarioot en die blougroenalg se sellulêre organisasie stem baie ooreen met die van bakterieë. Geen membraan-omgeefde organelle kom voor nie en die sel is verdeel in 'n sentrale sentroplasma en 'n chromatoplasma. DNA, ribosome en polihedrale liggaampies van die organisme word in die sentroplasma aangetref. RNA word in die sentroplasma sowel as die chromatoplasma aangetref. Polihedrale liggaampies word omring deur 'n proteïenmembraan wat verskil van die tipiese eenheidsmembraan. Lipiede word nie in die liggaampies aangetref nie. Dit wil voorkom asof die liggaampie verantwoordelik is vir die stoor van die ensiem Rubisco. Polihedrale liggaampies is dus waarskynlik betrokke by fotosintese, maar die Rubisco-ensiem kan ook 'n moontlike bron van stikstof wees.

Verskeie reserwe organiese stowwe kom in die chromatoplasma voor, bv. poliglikogeen-korrels, lipied-druppels wat gewoonlik met die wande geassosieer word, sianofisien-korrels en polifosfaat-liggaampies.

Tilakoïede kom verspreid in die chromatoplasma voor en bestaan uit eenheidsmembrane wat teen mekaar geleë is sonder 'n interne ruimte. Die aantal en rangskikking van die tilakoïede hang af van die fisiologie toestand en ontwikkelingsfase van die alg. Tilakoïedsenters is silinderagtige strukture met ronde subeenhede waaraan tilakoïedes vasgeheg is. Die organisme se assimilasiepigmente bestaan uit chlorofil a en fikobilisome wat aan die organisme sy blou kleur gee.

Oscillatoria simplicissima kan, soos die meeste ander blougroenalge, sy diepte in water reguleer met behulp van gasvakuole. Gasvakuole is silinderagtige, gasgevulde holtes, $0,1 \mu \mathrm{m}$ wyd en tot $1 \mu \mathrm{m}$ lank, met keëlvormige punte. Die wande van die strukture bestaan uit ' $n$ enkele soort proteien wat in riffels van $4,5 \mathrm{~nm}$ reghoekig tot die silinder gerangskik is. Die aminosure van die proteïen vorm hidrofobiese sykettings aan die binnekant van die silinder wat die vakuole deurlaatbaar maak vir gasse maar nie vir water nie.

Blougroenalge is eenvoudige oeroue prokariote met eenvoudige sellulêre organisasie wat groot opbloeie in Suid-Afrikaanse rivierstelsels vorm, en sodoende geweldige estetiese, ekonomiese en gesondheidsprobleme veroorsaak.

\section{Isosiem-merkers om twee morfologies eenderse Suid-Afrikaanse Mastomys-spesies (Rodentia: Muridae) te identifiseer}

\author{
A.K. Smit en F.H. van der Bank \\ Departement Dierkunde, Randse Afrikaanse Universiteit, Posbus 524, Aucklandpark, 2006 \\ T. de Castro \\ Departement Plantkunde, Randse Afrikaanse Universiteit, Posbus 524, Aucklandpark, 2006
}

Die twee Suid-Afrikaanse muisspesies Mastomys coucha en $M$. matalensis is morfologies identies in alle sigbare kenmerke, daarom is dit onmoontlik om hulle in die veld te identifiseer. Hulle is wyd versprei, en kom simpatries voor in sekere dele terwyl hulle allopatries in ander is. Dié muise is ook kommensaal met die mens, en die gewone huismuis kom in baie wonings voor. Hierdie saamleef met die mens is van mediese belang, omdat $M$. natalensis die virus wat Lassa Koors veroorsaak, en $M$. coucha die bakterie wat Builepes veroorsaak, dra.

Die individue is by twee lokaliteite versamel, naamlik by La Lucia Rif in Durban, en by Montgomerypark in Johannesburg.
Hart-, lewer-, spier-, nier- en bloed-weefselmonsters is geneem. Daar is gebruik gemaak van poliakrielamied en styseljel-elektroforese om die geenprodukte van 34 proteïen-gekodeerde lokusse te analiseer. Jel-elektroforese is die tegniek waarin verskillende proteïene in ' $n$ jel en elektriese veld skei, ten opsigte van hulle elektriese lading en grootte. 'n Verskeidenheid standaardkontinue en diskontinue buffers is gebruik. Die rekenaarprogram BIOSYS1 is ook gebruik om die resultate statisties te analiseer.

Drie isosiemmerkers is gevind: die glukose-6-fosfaat isomerase-2 (GPI-2)-lokus is nie in die lewer van $M$. coucha uitgedruk nie, en die algemene proteïen-koderende lokusse PT-2 en PT-3 is 
ook nie in al twee spesies se spier uitgedruk nie. Die genetiese afstand tussen die twee spesies was 0,123 , en die gemiddelde heterosigositeit was 0,019 vir $M$. natalensis en 0,038 vir $M$. coucha. Die resultate het dus bewys dat daar definitief twee aparte spesies is, en hierdie is die eerste studie wat genetiese variasie in, en tussen die twee spesies ondersoek het.

\title{
Invloed van temperatuur en fotoperiode op dae tot blom, opbrengs en opbrengskomponente van Lupinus albus (L.)
}

\author{
R. Keeve en J.A.M. van der Mey \\ LNR-Instituut vir Graangewasse, Privaat sak X1251, Potchefstroom, 2520
}

G.H.J. Krüger

Departement Plant- en Bodemwetenskappe, Potchefstroomse Universiteit vir CHO, Potchefstroom, 2520

As gevolg van die voortdurende vraag na hoër proteïen in diererantsoene word nuwe kultivars ontwikkel om aan die behoefte te voldoen. Die verskillende lupien-genotipes word beïnvloed deur lae temperature wat as vernalisasie dien en die periode van plant tot blom van die genotipe verleng of verkort. Die plante word hierdeur sodanig beïnvloed dat die plante of te lank word, of te kort bly (afhangende van die genotipe, lokaliteit en seisoen) wat die oesproses bemoeilik. 'n Beter begrip van die agronomiese belangrikheid van die plantdatum en die invloed van lae temperature en fotoperiode tydens ontkieming en plantontwikkeling mag lei tot beter bestuurstrategieë vir winter- en somerverbouing van die soet witlupien (Lupinus alhus). Die effek van plantdatum (temperatuur en fotoperiode) op dae tot blom, opbrengs en opbrengskomponente van vier vroeë tot medium en een laat groeiseisoen soet witlupien-genotipe is bestudeer in ' $n$ veldproef te Potchefstroom. Vogstremming is vermy deur gereelde besproeiing. Die invloed van temperatuur en fotoperiode op die duur van die ontwikkelingsfases vanaf die plantdatum tot ontkieming. ontkieming tot blominisiasie, inisiasie tot eerste visuele blom, duur van die blomperiode en dae tot fisiologiese rypheid en oesrypheid is bepaal. Blominisiasie is bepaal met behulp van 'n disekteermikroskoop as die datum van die oorgang van die apikale meristeem vanaf die vegetatiewe stadium na die generatiewe stadium. Verskille in die hoofkomponente van opbrengs, nl. sade per peul, sade per plant, peule per plant, enkelsaadmassa, enkelplantmassa, plant- en peulhoogte en opbrengs is bepaal. Met die berekening van die aantal dae tot blom van die verskillende genotipes is probeer om die groeitempo van die plant met hitteeenhede of termiese eenhede te verklaar. Die interaksie van genotipe en plantdatum was hoogs betekenisvol by beide die $\mathrm{P}<0,05$ of $\mathrm{P}<0,01$ peil vir die meeste eienskappe. Blomont- wikkeling van alle genotipes is hoogs gekorreleer met temperatuur en toenemende fotoperiode. Hierdie velddata is deur klimakabinetdata bevestig, $\mathrm{nl}$. dat hierdie lupien-genotipes soos langdagplante optree. Die invloed van temperatuur wat laer as 10 ${ }^{\circ} \mathrm{C}$ moet wees, speel ook ' $n$ rol deur die vernalisasie-effek wat tydens saadontkieming plaasvind. Daar is bevind dat die ontkiemingstempo laer was gedurende winter- en lente-aanplantings as gedurende someraanplantings, maar dat die tydperk tot blomvorming korter was gedurende winter- en lente- as gedurende someraanplantings, wat die effek van vernalisasie op die genotipes bevestig. Die interaksie tussen plantdatum en genotipe was hoogs betekenisvol vir saadopbrengs. Aangesien daar in hierdie studie bevind is dat Lupinus albus deur fotoperiode beinvloed word en soos langdagplante optree, word die invloed van fotoperiode ook in die vergelyking ingesluit en word die groeitempo van die genotipes dus eerder volgens fototermiese eenhede verklaar. Die bepaling van die groeitempo deur laasgenoemde vergelyking is die mees stabiele vir die genotipe Esta, ongeag die plantdatum. Die genotipe benodig ongeveer 1050 fototermiese eenhede om oor te gaan tot blom. Omrede die lengte van die groeiseisoen van 'n gewas of genotipe belangrik is in terme van die saadvullingsperiode en uiteindelik die opbrengspotensiaal, kan die fototermiese eenheid gebruik word om ten minste vir die Esta-genotipe die aantal dae tot blom te voorspel, sodat bepaal kan word of die toestande tydens die blom en saadvullingsperiode gunstig sal wees vir 'n optimale opbrengspotensiaal. Die beste saadopbrengs van $1,5 \mathrm{t} \mathrm{ha}^{-1}$ is behaal met die 10 Junie-aanplanting wat dus vir Potchefstroom as die beste plantdatum aangedui word. Vir warmer gebiede sal die plantdatum vroeër wees en vir koeler areas later. 


\section{Die aanpassing van soet witlupien (Lupinus albus)-kultivargroepe aan verskillende omgewingskategorieë in die somerreënvalgebiede van Suider-Afrika}

\section{J.A.M. van der Mey}

LNR-Instituut vir Graangewasse, Privaat sak X1251, Potchefstroom, 2520

Daar bestaan in Suidelike A frika 'n groot behoefte aan grane met 'n hoê proteïen- en energie-inhoud vir sowel mense as diere. Wit lupien (Lupimus albus), geteel vir lae alkaloiedinhoud en met 'n proteïeninhoud van $32 \%$, olie-inhoud van $10 \%$ en energie van 9$12 \mathrm{MJ} / \mathrm{kg}$, begin tans ' $\mathrm{n}$ rol speel by die vervulling van hierdie behoefte. Ondat hierdie gewas 'n koelweer-gewas is, moet die verskillende kultivargroepe egter by verskillende planttye vir verskillende klimaatsones aangeplant word.

Opbrengs en ander agronomiese data is versamel in lupienproewe oor ' $n$ periode van drie jaar, wat 33 omgewings verteenwoordig het. Uit die resultate van die kultivarproewe is drie kultivars gekies, wat in Suid-Afrika algemeen as aangepas aanvaar word. Hierdie kultivars is die langseisoenkultivar Esta en die mediumseisoenkultivars Kiev en Buttercup.

Opbrengskorrelasies van die gemiddelde opbrengs van hierdie kultivars en 'n reeks klimatologiese en grondkundige waarnemings is bereken.

Beide die kultivareienskappe en klimatologies betekenisvolle korrelasies is gebruik om geskikte gebiede, by verskillende planttye aan te dui.

Die AgroMet-program van die LNR-Instituut vir Grond, Klimaat en Water is gebruik om maandelikse kaarte te teken, waaruit dan areas met die regte klimaatsparameters vir die groejseisoen gekies is.

Opbrengste van die drie Lupinus albus-kultivars is afsonderlik en gemiddeld betekenisvol gekorreleer met:

Reënval van plant tot 60 dae na blom $(+0,60)$

Gemiddelde maksimum temperatuur van blom tot 60 dae na blom $(-0,65)$

$\mathrm{pH}(\mathrm{KCl})(+0,54)$.

Gemiddeld is 'n opbrengs van 2,7 ton ha-1 graan met 'n reënval van $488 \mathrm{~mm}$ en 'n temperatuur van $26,2^{\circ} \mathrm{C}$ oor die betrokke periodes verkry.

Aansienlike areas in die Vrystaat, Oostelike Hoëveld, KwaZulu-Natal en die noordelike gebiede wat geskik is vir lupienaanplantings in die koeler periodes van die jaar vir verskillende kultivargroepe, is geidentifiseer. Hierdie bevindings is ook belangrik vir die koeler dele van Afrika in die algemeen.

\section{Blaaranatomiese kenmerke van verteenwoordigers van Ruschia (Seksie Ruschia; Mesembryanthemaceae Fenzl.)}

\section{Schoeman, S.S. Cilliers, M.H. Buys en H. Krüger}

Departement Plant- en Bodemwetenskappe, Potchefstroomse Universiteit vir Christelike Hoër Onderwys, Potchefstroom, 2520

Die genus Ruschia Schwantes bevat ca. 345 spesies wat die hersiening van die genus as 'n geheel onmoontlik maak. Blaaranatomiese resultate wat hier weergegee word, vorm egter deel van 'n taksonomies-morfologiese hersiening van die seksie Ruschia wat uit slegs 14 spesies bestaan.

Die Ruschia-seksie Ruschia word gekenmerk deur sukkulente, kruisgewys teenoorstaande blare wat driehoekig is in deursnee, en waarvan die abaksiale kiel getand is. Die sittende blaarpare is aan die basis met mekaar en met die stingel vergroei. Verteenwoordigers van hierdie seksie kom voor in die Wes-, Oos- en Noord-Kaap, Oranje-Vrystaat en die Noordwes Provinsie.

Gedurende die ondersoek is blaarmateriaal, wat tydens drie afsonderlike geleenthede versamel is, in formaldehied-alkoholasynsuur (FAA) of paraformaldehied gefikseer. Blaarfragmente is daarna gedehidreer in 'n etanolreeks, met paraffienwas geinfiltreer en ingebed. Dwarssneë is gemaak met behulp van 'n roteermikro- toom en is histologies gekleur.

Daar is gevind dat verteenwoordigers van die seksie Ruschia 'n xeromorfiese epidermistipe besit. Die epidermistipe word geken aan die dik buitenste periklinale selwand; wat geimpregneer is met kalsiumoksalaatkristalle. Epidermisselle van hierdie tipe is eenvormig in grootte, met ingesinkte huidmondjies en 'n relatief dik waslaag wat die kutikula bedek.

Epidermisselle van die seksie Ruschia kan papilvormig of niepapilvormig wees. Twee tipes papille is geïdentifiseer, $\mathrm{nl}$. papille waarvan die buitenste periklinale selwand koepelvormig vertoon ( $R$. unidens, $R$ semidentata en $R$ ruralis), en 'n oorgangstipe tussen die Lithops- en die kegelseltipe ( $R$ perfoliata en Ruschia sp.) Twee tipes huidmondjies kom ook voor. Al die spesies bevat groot tannien-bevattende idioblaste wat direk onder die hipodermis voorkom, en rafiede wat in beide die chlorenchiem- en waterbergingsweefsel aangetref word. 


\title{
Filogenetiese verskille tussen agt kommersieel-belangrike broodboom- spesies deur middel van ensiem- en DNA-volgordebepalings
}

\author{
L. Brand, F.H. van der Bank en M. van der Bank \\ Randse Afrikaanse Universiteit, Posbus 524, Aucklandpark, 2006
}

P. Vorster

Universiteit van Stellenbosch, Privaat sak XI, Matieland, 7602

\author{
M. Wink en J. Treulein \\ Iniversiteit van Heidelberg, Im Neuenheimer Feld 364, 69120, Heidelberg, Duitsland
}

Die filogenetiese verwantskap tussen agt Encephalartos-spesies is bestudeer. naamlik: E. altensteinii Lehmann, E. arenarius R.A. Dyer, E. horridus (Jacquin) Lehmann, E latifrons Lehmann, E. lehmannii Lehmann, E. longifolins (Jacquin) Lehmann, E. princeps R.A. Dyer, E. rrispinowus (Hooker) R.A. Dyer, terwyl E. ferox as buitegroep gebruik is. Die motivering vir die studie is die feit dat die reproduktiewe en vegetatiewe morfologie nie ooreenstem nie. Gevolglik is ensiemelektroforetiese, asook DNAvolgordebepalings van die RbcL- en ITS-1 en -2 gene gedoen. Horisontale styseljel-elektroforese is op $12 \%$ jelle uitgevoer en die produkte van 20 ensiem-koderende lokusse is ondersoek. Standaardmetodiek is gevolg vir monster-voorbereiding, elektroforetiese tegnieke, ensiemk leurings en ekstraksiemetode vir DNA. Die ge-ekstraheerde DNA is vervolgens geamplifiseer deur middel van 'n PCR-reaksie, waarna die volgorde daarvan bepaal is. Die resultate van die ensiem-elektroforese toon dat die gemiddelde heterosigositeit van die broodbome die helfte minder is as vir goed-gedefinieerde spesies. Die resultate toon ook dat die variasie binne een van die spesies meer is as tussen al die spesies. Daar is gedokumenteerde voorbeelde van hibriede tussen hierdie spesies, wat dui op vrye geenvloei tussen die populasies. Die genetiese afstande toon dat hierdie broodboompopulasies van dieselfde spesie is. Die resultate van die DNA-volgordebepaling toon gemiddelde volgordeverskille van 1,158 , terwyl die buitegroep met gemiddeld 13 volgordes verskil van hierdie spesies. 'n Kladistiese ontleding van die DNA-data toon dat hierdie spesies in een groep val, terwyl die buitegroep in 'n ander groep val. Morfologiese kenmerke dui daarop dat daar agt verskillende spesies is. Daar is twee hipoteses ten opsigte van die filogenetiese verwantskappe (of tekort daaraan): 1) dat agt verskillende spesies verduidelik kan word deur onlangse divergensie en 2) dat hierdie agt spesies eerder 'n kliene vorm, met ander woorde 'n geleidelike oorgang op die eerste vlak van spesiasie.

\section{Allosiemvariasie in Afrika-olifante (Loxodonta africana) van die Nasionale Kruger-wildtuin}

\section{Greyling, F.H. van der Bank en M. Coetzee}

Olifante word al van 1898 af suksesvol in die Nasionale Krugerwildtuin bestuur en bewaar. Omdat olifantgetalle 5-7 persent per jaar toeneem, kan hulle vlakke bereik waar hulle die biologiese diversiteit van hulle habitat bedreig. Om hierdie rede word surplus olifante vanaf 1968 jaarliks uitgedun. Dit stabiliseer hulle getalle by 7000-7500. Maar nou ontstaan daar ' $n$ moontlikheid van inteling, aangesien die olifantbevolking oorspronklik ontstaan het uit slegs tien olifante. Dit word dus nou nodig om vlakke van genetiese variasie en die mate van inteling te bepaal. In 'n voorlopige studie van Coetzee el al. (1993) is die genetiese variasie van olifante in die sentrale deel van die Nasionale Kruger-wildtuin (NKW) bepaal. Die resultate het ' $n$ verlaging in genetiese variasie van nageslag tot nageslag getoon en ook ' $n$ verlaging in heterosigositeitwaardes. 'n Reduksie in genetiese variasie kan beteken dat toekomstige generasies meer vatbaar kan wees vir negatiewe invloede en minder adaptief vir omgewingsveranderinge. Omdat die resultate van die studie beïnvloed kan word deur die neem van klein steekproewe is die studie uitgebrei en is daar gekyk na 'n verskillende familiegroep in die noordelike deel van die NKW.

Bloed-. lewer-, hart-, nier- en spiermonsters is van olifante (Loxodonta africana) in NKW verkry gedurende die uitdunningsprogramme in April 1992 en Mei 1993. Weefselmonsters is in vloeibare stikstof gestoor tydens vervoer en daarna by $-20^{\circ} \mathrm{C}$ in die laboratorium gehou. Geenprodukte van 25 proteïengekodeerde lokusse is ondersoek deur gebruik te mak van horisontale styseljel-elektroforese, asook poliakrielamiedjel-elektroforese. Agtien proteïengekodeerde lokusse (72\%) in 1992 en $19(76 \%)$ in 1993 het monomorfiese jel-bandpatrone vertoon terwyl slegs sewe in 1992 en ses in 1993 polimorfies was. Gemiddelde heterosigositeitwaarde vir volwassenes, onvolwassenes en die totale bevolking in 1992 was onderskeidelik $0,058,0,024,0,047$. Laer waardes $(0,037,0,021$ en 0,033 onderskeidelik) is bepaal vir ' $n$ verskillende familiegroep in die huidige studie en statisties beduidende $(P<0,05)$ ooreenkomste tussen die alleel-verspreidings by vier van die agt polimorfiese lokusse van die twee olifantbevolkings is gevind. Die huidige studie bevestig die resultate van die vorige studie en variasie by 'n addisionele lokus word verskaf. Die data sal waardevolle inligting verskaf by die ondersoek van nuwe metodes om die getalle van olifantbevolkings te beheer sonder om waardevolle genetiese variasie te verloor. Voorts, die resultate by olifante waar groot monsters gebruik is, is belangrik vir die toekomstige monitering van geenvloei in populasies om vlakke van kruisteling en inteling te bepaal, en on die globale informasie op wildedierdiversiteit te vergroot. 


\title{
'n Ekologiese studie van die hervestigde Arabiese gemsbok Oryx leucoryx in die 'Uruq Bani Ma'arid Natuurreservaat van Saoedi-Arabië
}

\author{
W.M. Strauss \\ Sentrum vir Natuurlewebestuur, Universiteit van Pretoria, Pretoria, 0002
}

Die Arabiese gemsbok het uitgesterf in die natuur gedurende die jare sewentig as gevolg van benutting op 'n onvolhoubare basis. Gedurende 1984 is daar egter begin met 'n Arabiese gemsbokteelprogram in Saoedi-Arabië. Oor'n tweejaarperiode, vanafFebruarie 1995. het die Saoedi-Arabiese natuurbewaringsowerhede 65 A rabiese gemsbokke in die $12000 \mathrm{~km}^{2}$, onomheinde 'Uruq Bani Ma arid Natuurreservaat hervestig. Hierdie is slegs die tweede vrylewende Arabiese gemsbok-bevolking in die wêreld.

Gedurende 'n tweejaar-studieperiode is daar gekonsentreer op die ruimtelike verspreiding van die diere. Kwantitatiewe data is ook ingesamel met betrekking tot die voedingsgewoontes, daaglikse aktiwiteite en produktiwiteit van die gemsbokke.

Al die Arabiese gemsbokke in die natuurreservaat kan individueel herken word. Meer as $80 \%$ van die hervestigde diere is met radionekbande toegerus om monitering te vergemaklik. Vir die versameling van data oor die ruimtelike verspreiding is die gemsbokke daagliks opgespoor met behulp van radio telemetriese toerusting. Data versamel tydens elke waarneming sluit onder andere in ' $n$ GPS-posisie, tyd van die dag, habitattipe en samestelling, aktiwiteit van die diere en klimaatsfaktore. Hierdie data is aangevul deur waarnemings gedurende twee-weeklikse vlugte met 'n vastevlerkvliegtuig. Dié intensiewe monitering het ook data oor die produktiwiteit van die diere opgelewer.

Plantopnames is gedoen om die plantspesiesamestelling en die relatiewe hoeveelheid van elke spesie in die area te bepaal. Plantspesiebenutting van die diere is deur middel van direkte waarneming met 'n teleskoop ondersoek. In die voedingstudies is die hoeveelheid tyd gespandeer aan elke plantspesie, gelykgestel aan die belangrikheid van daardie spesie in die dieet.

Aktiwiteitstudies is gedoen deur waarnemings met vyfiminuutintervalle oor 'n periode van 12 ure. Die studies is tot die dagligure beperk as gevolg van probleme wat met die identifikasie van die diere gedurende die nag ondervind word.

In terme van ruimtelike benutting is daar gevind dat die area benut gedurende die eerste maand in die woestyn gewissel het tussen $184 \mathrm{~km}^{2}$ en $4573 \mathrm{~km}^{2}$ vir die ses vrylatingsgroepe. Loopgebiede word beinvloed deur reënvat. So is daar gevind dat die loopgebied gedurende die maand na wydverspreide reën drievoudig toegeneem het, in vergelyking met die loopgebied gedurende dieselfde periode voor die reën. Regressie-analise dui daarop dat volwasse bulle, volwasse kocie en onvolwasse koeie se afstand vanal die vrylatingspunt met tyd afneem, terwyl die afstand van onvolwasse bulle vanaf die vrylatingspunt met tyd toeneem.

Die basiese aktiwiteitspatroon van die Arabiese gemsbokke volg die tipiese patroon van daglewende hoefdiere, met voedingspieke in die vroeë oggend en laatmiddag. Die aktiwiteitspatrone van die diere word hoofsaaklik deur die seisoenale klimaatstoestande en die kwaliteit van die plantegroei in die reservaat beïnvloed.

Waarnemings het getoon dat $33 \%$ van die plantspesies wat benut is as voedingsplante aan die Poaceae-familie behoort. Alhoewel 33 van 'n moontlike 84 bekende plantspesies in die reservaat deur die gemsbokke benut is, is $70 \%$ van die waargenome voedingstyd aan grasspesies gespandeer.

Gedurende die tweejaarperiode is 39 Arabiese gemsbokkalwers gebore. Die gemiddelde ouderdom met eerste kalwing is 29,5 maande $( \pm 5,8$ maande $)(n=27)$. Die gemiddelde ouderdom met die geboorte van die tweede kalf is 38,8 maande ( $\pm 2,3$ maande) $(n=12)$, met ' $n$ gemiddelde interkalwingsperiode van 11,4 maande $( \pm 2,6$ maande). Gedurende dieselfde periode het ses volwasse diere ( $5: 1$ ) gevrek. Beserings wat opgedoen is as gevolg van gevegte was die oorsaak van dood by drie van die bulle.

Die Arabiese gemsbokbevolking blyk goed aan te pas in die 'Uruq Bani Ma' arid Natuurreservaat, soos waargeneem word deur die goeie aanteel en positiewe bevolkingsgroeitempo. Die insig van die Saoedi-Arabiese natuurbewaringsowerhede met hierdie hervestigingsprojek laat hoop vir verdere projekte, asook die langtermynoorlewing van die Arabiese gemsbok in die natuur.

\section{Die ergonomiese geskiktheid van kantoorstoele by 'n Suid-Afrikaanse technikon}

\author{
C. Weyers en D.J. van den Heever \\ Technikon Vrystaat, Departement Omgewingswetenskappe, Privaat sak X20539, Bloemfontein, 9300
}

Ergonomika verwys na die faktore wat die werker se gesondheid, welsyn en doeltreffendheid beïnvloed. Die faktore spruit voort uit die wisselwerking tussen die mens en die masjien en/of gereedskap wat hy beheer en/of hanteer, die werksfeer waarin hy beweeg en die ruimtelike beperkinge van sy liggaam.

Ergonomika het ' $n$ invloed op alle werkers aangesien hulle daagliks aan in werk en 'n werkplek blootgestel word. Die onvanpaste ontwerp van 'n kantoorstoel kan tot skeletale spierprobleme. pyn, moegheid en styfheid in die nek, skouers en voete, intervertebrale skyfbeskadiging, lumbale en servikale ruggraatprobleme, gelokaliseerde spiermoegheid, fisiese en emosionele ongemak en spierpyne aanleiding gee.

Die bogenoemde beinvloed die veiligheid, gesondheid, gemak en effektiwiteit van veral werkers. Daar is dus gepaardgaande finansiële implikasies as gevolg van siekteverlof, die voorkoms van ongelukke (na aanleiding van menslike foute) en mediese ongeskiktheid.

Verskeie bronne meld dat die werkstoel ontwerp is om $95 \%$ van die populasie te akkommodeer. Meer aandag behoort dus geskenk te word aan die oorblywende 5\% wat kort, lang, oorgewig, gestremde, ouer en jong persone asook verwagtende dames insluit (uiterstes). In hierdie gevalle behoort die werkstoel vir die individu ontwerp te wees.

Die studie is op 'n kwalitatiewe sowel as 'n kwantitatiewe navorsingsmetode gebaseer, aangesien dit 'n verkennende, beskrywende en vergelykende studie insluit. 
Een-en-twintig persent van die werknemers aan 'n technikon wat oor kantoorfasiliteite beskik, is as proefpersone in die studie gebruik $(n=81)$. Spesifieke afmetings met betrekking tot die kantoorstoele, sowel as die individue, is geneem, om sodoende 'n vergelyking tussen die persoon en sy/haar werkstoel te tref.

Alle data is met behulp van fisiese afmetings verkry en in die volgende datastelle ingedeel: armleuninghoogte teenoor die afstand vanaf die elmboog tot by die sitvlak (sittend); rugleuningwydte teenoor die rugbreedte; sitplekbreedte teenoor die sitvlakbreedte; sitpleklengte teenoor die afstand vanaf die sitvlak tot by die waai van die been en sitplekhoogte teenoor die afstand vanaf die waai van die been tot by die voet (sittend). Die rekenkundige gemiddelde en standaardafwyking van elke kategorie is statisties bereken. Die gemiddelde waardes wat sodoende vir die meubels verkry is, is met die antropometriese data van die persoon vergelyk.

Die ideaal is dat die werkstoelafmetings en die antropometriese afmetings in byna al die gevalle gelyk moet wees. Die sitplekbreedte teenoor die sitvlakbreedte is die uitsondering. Hier word net vereis dat die werkstoel breër as die sitvlakbreedte moet wees.

Die resultate van die studie toon aan dat die kantoorstoele nie volgens antropometriese afmetings geselekteer of verstel is nie. Betekenisvolle verskille is vir al die gevalle, behalwe die sitplekhoogte teenoor die afstand vanaf die waai van die been tot by die voet, tussen die antropometriese metings en afmetings van die meubels gevind (Student T. 'Toets, $p=0,05 . n-81$ ).

Dit is verkieslik dat verstelbare werkstoele aangekoop moet word, sodat 'n werker die kantoorstoel by sy/haar eie antropometriese afmetings kan aanpas. Die werknemers moet daarna ook deeglike opleiding ontvang sodat hulle die kantoorstoel korrek kan gebruik en/of verstel. Deeglike opleiding rakende die korrekte postuur asook die probleme wat kan ontstaan as gevolg van die verkeerde postuur moet verskaf word.

Spesiale aandag moet aan die persone buite die $95 \%$-reikwydte, wat kort, lang, oorgewig, gestremde, ouer, jong persone asook verwagtende dames insluit, geskenk word. Indien die werkstoelhoogte nie verstelbaar is nie, of die werkstoelhoogte na maksimum verstelling nog steeds te hoog is, kan van 'n voetrus/voetstoeltijie gebruik gemaak word. Dit is belangrik dat die werkstoel by die individu aangepas moet wees en alhoewel dit ekonomiese implikasies het, sal dit die voorkoms van ongemak en pyn in die ledemate verminder.

\title{
Die effek van die toetsomgewing op siftingsoudiometrie-resultate
}

\author{
C. Weyers en D.J. van den Heever \\ Technikon Vrystaat, Departement Omgewingswetenskappe, Privaat sak X20539, Bloemfontein, 9300
}

Ingevolge Suid-A frikaanse wetgewing moet oudiometriese toetse in 'n omgewing wat aan die vereistes van die Suid-Afrikaanse Buro vir Standaarde (SABS) voldoen, uitgevoer word. 'n SABSgebruikskode spesifiseer die maksimum toelaatbare omringende klankdrukpeile in die akoestiese omgewing wat vir siftingsoudiometrie gebruik word. Aangesien industrieë hoofsaaklik siftingsoudiometrie gebruik, het die standpunt ontstaan dat die gebruik van 'n akoestiese omgewing nie nodig is nie. Die rasionaal vir hierdie stelling is dat die gehoordrempel van persone met gehoorverlies nie tot so 'n mate deur die omgewingsklankdrukpeile beïnvloed word dat dit die siftingsproses sal affekteer nie.

'n Oudiometriese toets kan slegs die gehoorstatus van 'n persoon akkuraat bepaal indien geen maskering of omgewingsgeraas teenwoordig is nie. Omgewingsgeraas verlaag dus die hoorbaarheid van die toetssein en behoort die gehoordrempel van in persoon te beïnvloed.

'n Derde oktaafbandanalise is in die akoestiese en in die nieakoestiese omgewing uitgevoer om die klankdrukpeile by die verskillende frekwensies vas te stel.

Vrywillige mans- en damestudente, tussen die ouderdom van 18 tot 28 jaar, is in die studie gebruik $(n=126)$. Die proefpersone het ' $n$ gesondheidsgeskiedenis-vraelys ingevul en 'n otoskopiese ondersoek is uitgevoer. Oudiometriese toetse is volgens OSHA 29 CFR 1910.95, met gekalibreerde Tremetrics RA 400oudiometers, in die akoestiese en daarna in die nie-akoestiese ongewing uitgevoer.

Die data is in die verskillende frekwensies ingedeel en die rekenkundige gemiddeldes en standaardafwykings is statisties bereken. Die effek van die akoestiese omgewing op siftingsoudiometrie-resultate word deur die vergelyking van gehoordrempels in die akoestiese en in die nie-akoestiese omgewing geilllustreer.

Die resultate toon aan dat gehoordrempels in die akoestiese omgewing verskil van die gehoordrempels in die nie-akoestiese omgewing. 'n Betekenisvolle verskil bestaan tussen die akoestiese en die nie-akoestiese omgewing by die frekwensies van $500 \mathrm{~Hz}$ en $1000 \mathrm{~Hz}$ (Student T-toets, $p=0,05, n=126$ ). Die gehoordrempels in die akoestiese omgewing is laer as in die nieakoestiese omgewing. Die verskil kan moontlik verklaar word deur die aanwesigheid van hoër klankdrukpeile in die nieakoestiese omgewing wat tydens simulasie geproduseer word. Geen betekenisvolle verskil tussen die gehoordrempels in die akoestiese en die nie-akoestiese omgewing is by die frekwensies van $2000 \mathrm{~Hz}, 3000 \mathrm{~Hz}, 4000 \mathrm{~Hz}, 6000 \mathrm{~Hz}$ en $8000 \mathrm{~Hz}$ (Student Ttoets, $p=0,05, n=126$ ) gevind nie.

Die toetsomgewing beïnvloed gehoordrempel-bepaling veral by die laer frekwensies, en het dus ook 'n invloed op die kategorisering van 'n persoon se gehoorstatus. Die toetsomgewing blyk nie ' $n$ wesenlike verskil te maak by die identifisering van geraasgeinduseerde doofheid $(4000 \mathrm{~Hz})$ nie.

Daar word aanbeveel dat oudiometriese toetse altyd in 'n goedgekeurde akoestiese omgewing, wat aan die vereistes van die Suid-Afrikaanse Buro vir Standaarde voldoen, uitgevoer moet word om geldige en betroubare resultate te verkry.

Die resultate dui aan dat die voorgeskrewe ongewing toepaslik is vir die bepaling van gehoordrempels, en dus ook vir die kategorisering van 'n persoon se gehoorstatus. 


\title{
Die karakterisering van etileenoksied-emissies in 'n sweiswerkswinkel
}

\author{
C.E. Barnard en D.J. van den Heever \\ Technikon Vrystaat, Departement Omgewingswetenskappe, Privaat sak X20539, Bloemfontein, 9300
}

Data betreffende chroniese blootstellingsvlakke van etileenoksied $\left(\mathrm{C}_{2} \mathrm{H}_{4} \mathrm{O}\right)$ in die atmosfeer van sweiswerkswinkels is skaars, alhoewel voortdurende etileenoksied-blootstelling verskeie gesondheidseffekte op die werknemers kan hê.

'n Ondersoek is uitgevoer om die vlakke van etileenoksied in die werkomgewing van sweisers in 'n groot ingenieursaanleg in Bloemfontein te bepaal. Die doel van die ondersoek was die karakterisering van etileenoksied gedurende die somer- en wintermaande in sweiswerkswinkels ten einde die moontlike blootstellingstendense te bepaal.

'n Gerekenariseerde prosesmoniteringsisteem (PMS-64) met elektries-chemiese sensors is gebruik om etileenoksiedkonsentrasies met tussenposes van 30 minute te bepaal. Die stelsel is in die middel van die werkswinkel by 'n vaste basis geinstalleer. Data is vir een week van elke maand vanaf Februarie 1997 tot Julie 1997 op 'n 24-uur deurlopende basis versamel, om sodoende lesings vir die somer-sowel as wintermaande te bekom. Die data is tot ' $n$ agtuur-Tyd-Beswaarde Gemiddelde (TBG)-konsentrasies en weeklikse TBG-konsentrasies verwerk.

Die Nasionale Instituut vir Beroepsveiligheid en Gesondheid $(\mathrm{NIOSH})$ in die VSA stel 'n beroeps- $\mathrm{C}_{2} \mathrm{H}_{4} \mathrm{O}$ TBG-DLW (Drempellimietwaarde) van $0,1 \mathrm{dpm}$ vir 'n agtuur-blootstelling. $\mathrm{C}_{2} \mathrm{H}_{4} \mathrm{O}$-konsentrasie wat die DLW oorskry, kan mutasies, neurotoksiese en karsinogeniese effekte by die mens veroorsaak.

Somermaande: Gedurende Februarie 1997 is die hoogste TBGkonsentrasie van $0,45 \pm 0,21 \mathrm{dpm}$ verkry. Hierdie waarde oorskry die aanbevole beroeps-DLW van $0,1 \mathrm{dpm}$. Konsentrasies gemeet gedurende Februarie het nooit benede $0,1 \mathrm{dpm}$ gedaal nie. Die gemete konsentrasie vir Maart 1997 het met tye benede die deteksielimiet gedaal, maar die agtuur-TBG-konsentrasie van elke dag het steeds die aanbevole beroeps-DLW van 0,1 dpm oorskry.
Gedurende April 1997 is bykans dieselfde resultate verkry, met die uitsondering dat die agtuur-TBG-konsentrasie $(0,04 \pm 0,05$ $\mathrm{dpm}$ ) op Dinsdag (15/04/97) nie die DLW oorskry het nie

Wintermaande: Die Mei-maand TBG-konsentrasie van $0,17 \pm$ $0,23 \mathrm{dpm}$, met 'n maksinum van 1,7 dpm is gemeet. Die blootstelling op Woensdag, Donderdag en Vrydag was onderskeidelik 13,5, 14 en 10,1 keer meer as die beroeps-DLW van $0,1 \mathrm{dpm}$. Die daaglikse konsentrasie in Junie 1997 was op Dinsdag en Woensdag benede die TBG-DLW. Die DLW was dus vir drie dae van die week oorskry. Gedurende Julie 1997 is die laagste TBG-konsentrasie van $0,15 \pm 0,47 \mathrm{dpm}$, asook die hoogste maksimum waarde van $5,2 \mathrm{dpm}$ gevind.

Die afname in $\mathrm{C}_{2} \mathrm{H}_{4} \mathrm{O}$ kan aan verskeie redes, soos die werkslading wat verskil en die atmosferiese omstandighede soos wind wat konsentrasies verdun het, toegeskryf word.

Die relatief hoë $\mathrm{C}_{2} \mathrm{H}_{4}(\mathrm{O}$-konsentrasies in die werkswinkel is moontlik die gevolg van die suurstof-asetileen-sweisproses wat daagliks gebruik word. Die $\mathrm{C}_{2} \mathrm{Il}_{4}$ ()-konsentrasies het 'n kenmerkende toename in die lug getoon sodra die werksaamhede bedags begin is. Alhoewel $\mathrm{C}_{2} \mathrm{H}_{4}()$-konsentrasies meer geredelik gedurende die somer as die winter voorgekom het, is hoër maksimum konsentrasies gedurende die winter aangeteken. Die resultate beklemtoon die belangrikheid van blootstellingskarakterisering tydens industriële prosesse, ten einde lugkontaminante te identifiseer en om vrystellingsbronne effektief te bestuur.

Die werkers wat aan die gemete $\mathrm{C}_{2} \mathrm{Il}_{4} \mathrm{O}$-konsentrasies in die omgewingslug binne die werkswinkel blootgestel word, kan gesondheidsprobleme ná voortdurende blootstelling ervaar.

\section{Kwantifisering en karakterisering van koolstofmonoksied-binnedringing in ligte motorvoertuie tydens langafstand-padverkeerstoestande}

\section{D.J. van den Heever}

Technikon Vrystaat, Departement Omgewingswetenskappe, Privaat sak X20539, Bloemfontein, 9300

Koolstofmonoksied is 'n kleurlose, smaaklose en reuklose gas wat gevorm word tydens onvolledige verbranding van koolstofbevattende materiaal. Dit is algemeen bekend dat motorvoertuie groot hoeveelhede koolstofmonoksied as motoruitlaatgas vrylaat. Aangesien die moontlikheid bestaan dat koolstofmonoksied wat deur voertuie uitgelaat word ander motors kan binnedring en ' $n$ mate van vergassing kan veroorsaak, is ' $n$ studie uitgevoer om die omvang van sodanige binnedringing in ligte passasiersmotors vas te stel. Die doel van die studie was om die binnedringing van koolstofmonoksied in motorvoertuie tydens voortsnelling op 'n openbare pad te kwantifiseer en om faktore wat binnedringing bevoordeel, te identifiseer.

'n Gekalibreerde Oldham MX-21 multi-gasmoniteringsisteem is op die voorste sitplek van 'n ligte passasiersmotor geplaas en die ventilasiesisteem is sodanig gestel dat lugvoorsiening direk op die elektries-chemiese sensors plaasgevind het. Monitering het oor ' $n$ afstand van een duisend kilometer en 'n tydperk van tien ure aaneenlopend plaasgevind. Monsterneming het in Langebaan aan die weskus van Suid-Afrika begin en 'n roete wat deur die Karoo tot in Bloemfontein strek, is gevolg. Data is met tussenposes van een minuut as ' $n$ gemiddelde waarde in die geheue van die instrument gestoor. Ten einde koolstofmonoksied vanaf motoruitlaatgasse positief te identifiseer, is petroldampe as merker gebruik wat gelyktydig deur die instrument gemonster is.

Aangesien faktore soos windsnelheid, windrigting, snelheid, volgafstand en ander meteorologiese toestande nie tydens hierdie studie konstant was nie, is resultate met groot reikwydtes verkry. Koolstofmonoksied-konsentrasies het tussen 0 en 30 dele per miljoen gewissel ( $95 \%$ VI; 1,004-1,023). Petrolgasse het, soos verwag is, 'n toename getoon wanneer CO-konsentrasies in die motor toegeneem het. 'n Minimum waarde van $22 \%$, en 'n maksimum waarde $27 \%$ is vir die laer ontploffingslimiet van petrol gedurende die studie aangetoon.

Die resultate van die studie toon dat koolstofmonoksied wel in 
'n motor sc kajuit opbou, veral wanneer ander motors gevoly word. ' $n$ Verdere bydraende faktor is die plasing van die voorste motor se uitlaatstelsel en die varslug-inlaatstelsel van die motor waarin gereis word. Byna alle motors se varslug-inlaatstelsels is onder dic enjinkap geïnstalleer en indien die voorste motor se uitlaatstelsel direk na die motor daaragter wys, word groter hoeveelhede koolstofmonoksied in die agterste motor ingelaat.

Blootstellingsdrempels van 50 dele per miljoen (dpm) en 25 dpm word respektiewelik deur owerhede in Amerika en SuidAfrika as veilige konsentrasies tydens blootstelling vir 'n maksimum tydperk van agt ure voorgeskryf. Hierdie blootstellingsdrempels is gebaseer op die anoksiese effek van CO asook die effek op die mens se kardio-vaskulêre stelsel, sentrale senuweestelsel en voortplantingstelsel. Die maksimum konsentrasie wat tydens die studie gevind is, het die Amerikaanse veiligheidstandaard vir enkele minute oorskry, alhoewel die tydbeswaarde gemiddelde konsentrasie veel laer as die veiligheids- grens was. Bestuurders sal nogtans 'n mate van vergiftiging ervaar wanneer hulle aan hoë CO-konsentrasies vir kort periodes gedurende 'n lang rit blootgestel word.

Indien lang ritte onderneem word waartydens 'n bestuurder vir periodes van 15 tot 30 minute agter ander voertuie volg, kan groot hoeveelhede $\mathrm{CO}$ die motor binnedring wat geringe akute $\mathrm{CO}$ vergiftiging en visuele verswakking tot gevolg kan hê. Daar word aanbeveel dat motorbestuurders veel eerder die motor se ventilasiestelsel verstel sodat die varslug-inlaat afgesluit word en slegs gesirkuleerde lug ingeasem word wanneer motors op " $n$ pad gevolg word. Die afsluiting van die varslug-inlaatstelsel sal verhoed dat $\mathrm{CO}$ van ander voertuie op die pad die motor binnedring. Varslug-inlaatstelsels van motors behoort ook met 'n COabsorbeerder toegerus te wees ten einde binnedringing van die gas in die motor te beperk. Die studie word tans in verskillende padverkeerstoestande uitgevoer ten einde die verskillende blootstellings te karakteriseer.

\section{Spinnekopdiversiteit in Afrika: geleenthede en uitdagings}

\section{A.S. Dippenaar-Schoeman}

LNR-Navorsingsinstituut vir Plantbeskerming, Privaat sak X134, Pretoria, 0001

\section{$\mathrm{R}$. Jocqué}

Koninklijk Museum voor Midden-Afrika, B-3080 Tervuren, België

Tydens ' $n$ konferensie van die Verenigde Nasies in Rio de Janeiro (1992) wat gehandel het oor die omgewing en die ontwikkeling daarvan, is verskeie besluite geneem. Die Konvensie van Biologiese Diversiteit is daargestel en deur die meeste lande, ook SuidAfrika, onderteken. Dit verplig hulle om aan die volgende aspekte aandag te gee: die bewaring van die bestaande biodiversiteit van die aarde; die gebruik van die bestaande biologiese bronne op 'n onderhoubare wyse en die gelyke en regverdige verdeling van voordele wat daaruit mag voortspruit. Die sistematici van die wêreld het die belangrike rol wat taksonomie en sistematiek in hierdie verband kan speel, besef en 'n projek, Sistematiek 21 , in die lewe geroep met die einddoel "om die spesies van die wêreld te ontdek, te beskryf en te klassifiseer".

Die Nasionale Versameling van Arachnida by die LNR-Navorsingsinstituut vir Plantbeskerming het hierdie geleentheid gebruik om hulle uitgebreide literatuur- en eksemplaar-databasis van Afrika se arachneofauna onder een projek saam te vat, genaand die Afrika Arachnologiese Databasis (AAD). Een van die doelwitte met die stigting van die AAD in 1996 was om 'n inventaris te hou van Arachnida-spesies wat in Afrika voorkom. Een van die eerste projekte van die AAD is onlangs suksesvol voltooi met die daarstelling van ' $n$ handboek wat sleutels bevat tot die 7 I spinnekopfamilies wat in die A frotropiese Wyk voorkom.

Afrika, en wel die Sub-Sahara-streek (die Afrotropiese Wyk) word deur 'n ryke verskeidenheid biome gekenmerk; van tropiese reënwoude tot woestyne. Hierdie diversiteit word ook deur die spinnekopfauna gereflekteer. Verteenwoordigers van twee-derdes van die wêreld se spinnekopfamilies kom in die A frotropiese Wyk voor. in total 71 families, 893 genera en 5450 spesies. Dit vergelyk goed met die 3412 spesies wat in die Verenigde State van Amerika voorkom en die 2400 spesies van Australié. Ongeveer $70 \%$ van die spinnekopgenera van Afrika is tussen die jare 1800 en 1920 beskryf, hoofsaaklik deur arachnoloë wat die kontinent vir kort periodes besoek het. Hierdie tendens het 'n invloed op taksonomiese studies van vandag, deurdat meeste van die genera swak beskryf is, sonder tekeninge gepubliseer is, en dat die tiepmateriaal in instansies en versamelings dwarsoor die wêreld verspreid is. 'n Hoê persentasie van endemisme (56\%) kom voor op generiese vlak, terwyl $9 \%$ van die genera 'n Gondwanaland-verspreiding toon en $3 \%$ uitheemse genera in Afrika verteenwoordig. 'n Oorsig oor die stand van spinnekoptak sonomie toon dat slegs $16 \%$ van die totale getal genera wat bekend is, reeds hersien is. Resultate van hierdie hersienings toon dat ongeveer $41 \%$ spesies as nuut beskryf word, terwyl $32 \%$ as sinonieme aangewys is en $24 \%$ van die genera monotipies is.

Min is bekend oor die bio-ekologie van die spinnekoppe van Afrika. Navorsing op beide spesievlak en ekosisteme, is hoofsaaklik beperk tot die Ivoorkus, Ghana, Kenia, Namibië en SuidAfrika. Hierdie tekortkoming kan grotendeels toegeskryf word aan gebrekkige taksonomiese kennis van die spinnekopspesies wat bioloë ontmoedig om die organismes te bestudeer. Taksonomie bly die onvervangbare basis van alle biologiese, biotegnologiese, molekulêre, genetiese en ander toegepaste navorsingsvelde. Dit beklemtoon ook die dringende noodsaaklikheid van poste vir goed opgeleide taksonome om aandag te gee aan die diversiteit van Afrika se arachneofauna. 


\title{
Uitdrukking van gonadotropien-vrystellingshormoon-reseptor in muis en rot testikulêre kiemselle
}

\author{
C. Huyser \\ Departement Obstetrie en Ginekologie, Universiteit van Pretoria, Posbus 667, Pretoria \\ P. Bull en T. Socias \\ Universidad Católica de Chile
}

E.A. Castellón

ICBM, Universidad de Chile

P. Morales

Universidad de Antofagasta, Chile

Die doel van die studie was om die uitdrukking van gonadotropien-vrystellingshormoon-reseptor (GnRHR) in kiemselle van muis- en rot-testisweefsel, deur middel van Noordelike hibridisasie, te bepaal. Onvolwasse muise (C57B I-MDX, 22 dae oud, $N$ $=6-8 /$ eksperiment) en rotte (Sprague-Dawley, 30 dae oud, $N=$ 4-6) is deur servikale dislokasie gedood. Individuele kiemselfraksies is deur middel van ensiemmatiese prosedures vanuit testisweefsel verkry. Totale ribonukleïensuur (RNA) is van individuele kiemselfraksies, sowel as heel testisse, hipofisekliere en muis-ovariums onttrek. Die RNA-fraksies is deur formaldehied-agarjel elektroforeties geskei, oorgedra na nylonmembrane, gehibridiseer met 'n muis GnRHR ${ }^{32} \mathrm{P}$-gemerkte cDNA-pyler en met behulp van outoradiografie gevisualiseer.
Mikroskopiese evaluasie van geïsoleerde kiemselpreparate dui die voorkoms van $\geq 80 \%$ mid- en laat-pagiteen spermatosiete aan. Noordelikeblot-analise het ' $\mathrm{n}$ enkel band van $3,9-4,3 \mathrm{~kb}$ in rothipofises onthul. In rot-testisse en -kiemselle is drie onderskeie transkripsies van $3,2-3,8,2,0-2,22$ en $1,2-1,4 \mathrm{~kb}$ waargeneem. Muis-hipofises en -ovariums het twee reseptortranskripsies van 4,3-5,2 en 3,5 kb vertoon. 'n Kleiner boodskapper-RNA GnRHRtranskripsie van $1,7-1,8 \mathrm{~kb}$ is ook in muis-testisse waargeneem. Gonadotropien-vrystellingshormoon-reseptor wat teenwoordig is in kiemselle mag dus moontlik 'n interaksie hê met GnRH of GnRH-agtige peptiede, wat in die testis geproduseer word, en dit kan moontlik deel vorm van die parakrienestelsel.

\section{Baba gebore na terugplasing van ontvriesde embrio's: 'n Gevallestudie}

\author{
T.H. Brits, E. Radloff, J.E. Meintjes, W.K.H. Kuchenbecker, C. Huyser en B. de Nysschen \\ Departement Obstetrie en Ginekologie, Universiteit van Pretoria, Posbus 667, Pretoria, 0001
}

'n Egpaar met primêre infertiliteit vir vier jaar het 'n derde poging tot geassisteerde reproduksie ondergaan. 'n Erge oligo-terato-astenosoöspermie (OTA)-sindroom en polisistiese ovariële sindroom (PSOS) is onderskeidelik by die manlike en vroulike pasiënt gediagnoseer. Na gekontroleerde ovariële hiperstimulasie is 27 oösiete met ultraklank-ondersteunde transvaginale aspirasie herwin. Intrasitoplasmiese sperm-inspuiting (ISSI) is op 20 metafase 11- en 4 profase I-oösiete uitgevoer, waarna $62,5 \%$ van die oösiete bevrugting getoon het. Vier embrio's is in die uterus teruggeplaas. Agt oorblywende embrio's is bevries met behulp van 'n outomatiese biologiese bevrieser (PLANER). Sukrose en 1,2-propaandiol $(\mathrm{PROH})$ is as kriopreserveermiddels gebruik. Die embrio's is in vloeibare stikstof teen $-196{ }^{\circ} \mathrm{C}$ bewaar. Die swangerskaptoets 10 dae na embrioterugplasing was negatief.

Die egpaar het terugplasing van ontvriesde embrio's in ' $n$ toe- komstige ongestimuleerde siklus versoek. Embrio-ontvriesing is 103 dae na die aanvanklike bevriesingspoging deur stapsgewyse verwydering van die PROH-kriopreserveermiddel uitgevoer. Hierna is die embrio's vir 24 uur in M3-medium by $37^{\circ} \mathrm{C}$ geïnkubeer.

Vier ontvriesde embrio's is op dag 22 van 'n natuurlike siklus in die uterus teruggeplaas en 10 dae later was die swangerskapstoets positief. 'n Gesonde babadogtertjie met 'n massa van 3,42 $\mathrm{kg}$ is op voltyd met behulp van ' $\mathrm{n}$ keisersnit gebore: die eerste baba gebore in ons eenheid na die terugplasing van ontvriesde embrio's verkry na die ISSI-prosedure. Terugplasing van ontvriesde embrio's later in die luteale fase in vergelyking met terugplasing van vars embrio's na in vitro-bevrugting of ISSI, mag die kumulatiewe sukseskoers van hierdie prosedures verbeter. 